\title{
Zagotavljanje enakosti spolov v slovenski lokalni samoupravi
}

\author{
UDK: 352:342.726(497.4)(045)
}

\author{
Roman Lavtar \\ Služba Vlade RS za lokalno samoupravo in regionalno politiko \\ roman.lavtar@gov.si
}

\begin{abstract}
IZVLEČEK
V slovenski strokovni in politični javnosti je zagotavljanje enakosti spolov $v$ zadnjem desetletju v primerjavi s preteklim obdobjem deležno večje pozornosti. Številni spodbujevalni ukrepi, podprti $z$ zakonodajo in ustanovitev posebnega državnega organa, ki sistematično spremlja omenjeno vsebino, so povzročili velikanski skok tako pri razumevanju družbene teže razmerja med spoloma kot tudi konkretne rezultate pri zagotavljanju enakosti spolov v Republiki Sloveniji. V prispevku avtor sistematično ovrednoti razmere v sistemu lokalne samouprave, kot vertikalno decentraliziranem podsistemu javne oblasti. S kvantitativnega vidika tudi pri sodelovanju žensk v odločanju na lokalni ravni beleži opazen napredek. Avtor napoveduje še nadaljnjo krepitev vloge žensk pri lokalnem političnem odločanju, saj se bo s povečevanjem zahtevanega števila obeh spolov na kandidatnih listah ustvarila kritična masa lokalnih političark in vzpostavila razmerje, $v$ katerem se bosta $h$ kvotam in zadrgi v prihodnje zatekala oba spola.
\end{abstract}

Ključne besede: enakost spolov, lokalna samouprava, občina, volitve, participacija

JEL: K39, Z1

\section{Demokracija in ženske}

Z današnjega vidika je bila antična grška mestna državica vse prej kot demokratična, saj so se pravice sodelovati pri upravljanju javnih zadev nanašale izključno na svobodne moške. Ženske, sužnji in tujci so bili iz teh procesov izključeni (Held, 1989: str. 45). Od sredine 15. stoletja, ko se je Machiavelli kot prvi teoretik sodobne države oddaljil od srednjeveškega pogleda na državo in demokracijo, pa do konca 19. stoletja so teoretiki demokracije vztrajali pri 


\section{Roman Lavtar}

\section{Zagotavljanje enakosti spolov v slovenski lokalni samoupravi}

zahtevi, da lahko volijo le beli moški z lastnino. Sodoben pogled na državljanske in politične pravice je radikalno drugačen. Zlasti v novejšem obdobju se je razvila tudi t. i. ženska politika, ki jo opredeljujejo kot politiko proti podreditvenim razmerjem, povezanimi s spolom in ki hoče oblikovati tako zakonodajo in prakso, ki bi ženskam omogočila zasedanje enakih položajev kot moškim in ki bi deklarirano enakost uveljavila tudi v praski. To ni politika zgolj žensk, čeprav so te $\vee$ gibanju najbolj številne. Med različne načine zastopanja posebnih ženskih interesov in organiziranja žensk uvrščajo posebne ženske politične stranke, krovne organizacije ali civilno družbena gibanja, večina političnih strank pa ima v svojih političnih programih posebne programske resolucije ali celo sistem kvot za znotraj strankarske organe ali/in oblikovanje kandidatnih list na volitvah (Antic in Mencin, 1992: 107). Zavedanje o nujnosti posebnega varovanja posameznih družbenih skupin so veliko mlajša od izuma demokracije. John Stuart Mill je, ko je opredeljeval liberalno demokratično državo, tej predpisoval dejavno vlogo pri zavarovanju pravic ljudi s sprejemanjem zakonov, ki varujejo skupine, kakršne so etnične manjšine in ženske. Še posebej položaj slednjih je bil predmet njegovega izrecnega zanimanja. Po Millu lahko ustvari ustrezne razmere za človeško svobodo in demokracijo le popolna enakost med moškimi in ženskami $\checkmark$ vseh političnih in družbenih strukturah. $\vee$ eseju, objavljenem $v$ letu 1859, O svobodi je zapisal, da za ukinitev despotske oblasti moža nad ženo ni treba nič drugega, kot dati ženskam enake pravice in jih z zakonom enako varovati kot moške (Mill, 1988: 187). Njegov predlog, da bi leta 1867 britanski parlament izglasoval zakon, s katerim so približno milijonu delavcev dali volilno pravico, da bi jo hkrati priznali tudi ženskam, pa je doživel neuspeh. Prva država, ki je uvedla žensko volilno pravico, je bila tako leta 1893 Nova Zelandija. Že več kot pol stoletja pred Millom je z Zagovorom pravic ženske, objavljenim leta 1792, do podobnih ugotovitev prišla Wollstonecraftova, po krivici zapostavljena ena ključnih teoretičark razvojne demokracije, ko je pritrjevala misli, da je to, da ena polovica človeškega rodu izključuje drugo iz vsakega sodelovanja pri vladanju, politični fenomen, ki ga z abstraktnimi načeli ni mogoče pojasniti (Wollstonecraft, 1993: 5). Uvedba ženske volilne pravice kot enega najpomembnejših načinov participacije žensk $v$ političnem odločanju je na Slovenskem povezana $z$ uvedbo volilne pravice $v$ stari Avstriji sploh. Po zlomu absolutizma sredi 19. stoletja so imele ženske volilno pravico na občinski in deželni ravni od leta 1863, kadar so bile davkoplačevalke. Kljub volilni pravici niso smele na volišča, ampak so zanje volili možje, očetje ali bratje. Na državni ravni so splošno volilno pravico dobile šele leta 1907, sicer različno po posameznih deželah, na Goriškem na primer šele po razpadu monarhije (Melik, 1965: 115 -116). 
$\checkmark$ zadnjem četrt stoletju se je tako $v$ svetu kot pri nas bolj kot kdajkoli prej postavilo vprašanje, ali je demokracija brez enake zastopanosti obeh spolov sploh demokracija. T. i. paritetna demokracija predvideva enako zastopanost obeh spolov na vseh področjih življenja, tudi političnega. Še leta 1991 je bilo v nacionalnih parlamentih držav po svetu v povprečju le 11 \% žensk, v takratnih članicah Evropske unije 12,5 \%. Po padcu berlinskega zidu pa je $\vee$ Evropi stopnja še padla, kar dokazuje, da več demokracije ne pomeni nujno več žensk $v$ politiki. Koncept paritetne demokracije zahteva de iure in de facto enako zastopanost spolov, zavrača kulturni relativizem kot oviro (kulture, vera ali tradicija ne morejo biti ovira za uresničevanje paritetne demokracije) in zahteva od držav, da s konkretnimi ukrepi zagotovijo legitimne zahteve žensk, saj gre za univerzalno in nedeljivo človekovo pravico (The gender parspective, 1995: 12 - 14). V tabeli 1 so podatki iz leta 2002, po katerih so se slabše od Slovenije uvrščale le še nekatere evropske države.

Tabela 1: Odstotek žensk med župani in svetniki v nekaterih evropskih državah 2002

\begin{tabular}{|l|c|c|}
\hline \multirow{2}{*}{ Država } & \% žensk med župani & \% žensk med svetniki \\
\hline Albanija & 3,0 & 10,6 \\
\hline Avstrija & 1,7 & $\ldots$ \\
\hline Belgija & 7,6 & 27,0 \\
\hline Bolgarija & 8,0 & 20,0 \\
\hline Ciper & 3,0 & 19,8 \\
\hline Finska & $\ldots$ & 34,0 \\
\hline Francija & $\ldots$ & 47,5 \\
\hline Hrvaška & $\ldots$ & 4,0 \\
\hline Islandija & 3,0 & 29,0 \\
\hline Italija & 6,6 & 16,7 \\
\hline Liechenstein & $\ldots$ & 21,4 \\
\hline Litva & 5,0 & 21,4 \\
\hline Luksemburg & 10,2 & 16,7 \\
\hline Madžarska & 13,0 & 9,1 \\
\hline Makedonija & 21,4 & 8,4 \\
\hline Malta & 7,6 & 20,2 \\
\hline Norveška & 15,0 & 34,0 \\
\hline Poljska & 5,3 & 13,2 \\
\hline Portugalska & 4,9 & $\ldots$ \\
\hline Romunija & 3,4 & $\ldots$ \\
\hline Slovaška & 16,9 & $\ldots$ \\
\hline Slovenija & 5,7 & 13,1 \\
\hline Španija & 9,6 & $\ldots$ \\
\hline Švedska & $\ldots$ & 42,0 \\
\hline Švica & $\ldots$ & 28,0 \\
\hline Turčija & 0,4 & $\ldots$ \\
\hline
\end{tabular}

Vir: http://www.unece.org/stats/trends/ch12/12.7.xls, povzeto po Statistični urad Republike Slovenije, 2007 


\section{Roman Lavtar}

\section{Zagotavljanje enakosti spolov v slovenski lokalni samoupravi}

\section{Slovenija po osamosvojitvi in participacija žensk}

Razprava o enakosti moških in žensk ima v Sloveniji v obdobju osamosvojitve kot politična tema precej dolgo tradicijo. Parlament je že leta 1990 ustanovil Komisijo za žensko politiko, v obdobju 1996 - 2000 je ustanovil Komisijo za politiko enakih možnosti, leta 1992 je vlada dobila poseben Urad za žensko politiko, ki se je po letu 2000 preimenoval v Urad za enake možnosti. Prav Komisija za žensko politiko je ob obravnavi Zakona o političnih strankah leta 1994 predlagala dopolnitev, s katero so $v$ besedilu pričeli uporabljati žensko in moško slovnično obliko. Njen predlog, da bi se politične stranke bolj odločno zavezale k zagotavljanju enakih možnosti pri določanju kandidatur za volitve (z eno tretjino kandidatk), pa državni zbor ni sprejel. Komisija je zahtevala obvezno razlago določbe 5. točke 19. člena zakona na način, da bi statut politične stranke natančno določal ukrepe in postopke pri določanju kandidatnih list za volitve, vendar tudi te razlage državni zbor leta 2000 ni podprl. Do bolj določnih zakonodajnih potez je moralo preteči še nekaj časa.

Temelji za uravnoteženo zastopanost žensk in moških v predstavniških organih so opredeljeni v Ustavi Republike Slovenije. Ta v četrtem odstavku 43. člena $\vee$ povezavi s 44 . členom ${ }^{2}$ določa, da zakon določi ukrepe za spodbujanje enakih možnosti moških in žensk pri kandidiranju na volitvah $v$ državne organe in organe lokalnih skupnosti. Na podlagi te določbe, ki jo je prinesel Ustavni zakon o spremembi 43. člena Ustave Republike Slovenije, ki ga je Državni zbor Republike Slovenije sprejel na seji dne 15. junija 2004, je zakonodajalec kasneje sprejel ukrepe $\vee$ več zakonskih predpisih. Julija 2002 je bil sprejet Zakon o enakih možnostih žensk in moških (ZEMŽM) U. I. RS, št. 59/02 in 61/07), s katerim je določil temelje za izboljšanje položaja žensk in ustvarjanje enakih možnosti žensk in moških na političnem, ekonomskem, socialnem, vzgojnoizobraževalnem ter na drugih področjih družbenega življenja (1. člen). Na tej podlagi sta bili kasneje sprejeti še Uredba o pogojih in merilih za sofinanciranje projektov na področju enakih možnosti žensk in moških, Ur. I. RS, št. 80/03 in Uredba o pogojih in merilih za sofinanciranje projektov na področju enakih možnosti žensk in moških, Ur. I. RS, št. 103/04. Maja 2004 je bil sprejet Zakon o uresničevanju načela enakega obravnavanja (uradno prečiščeno besedilo) (ZUNEO-UPB1) Ur.I. RS, št. 93/2007, ki določa skupne temelje in izhodišča za

1 Vsak državljan ima pravico, da v skladu z zakonom neposredno ali po izvoljenih predstavnikih sodeluje pri upravljanju javnih zadev. 


\section{Roman Lavtar \\ Zagotavljanje enakosti spolov v slovenski lokalni samoupravi}

zagotavljanje enakega obravnavanja vsakogar pri uveljavljanju njegovih ali njenih pravic in obveznosti ter pri uresničevanju človekovih pravic in temeljnih svoboščin (1. člen). Zakon odloča tudi subjekte, ki z ukrepi v okviru svojih pristojnosti ustvarjajo pogoje za uresničevanja načela enakega obravnavanja in vzpostavlja institucionalne pogoje za delovanje novega instituta, zagovornika oziroma zagovornice načela enakosti, ki z obravnavo primerov domnevnega neenakega obravnavanja nudi pomoč diskriminiranim osebam. Z ZUNEO je država v slovenski pravni red prenesla tudi šest direktiv Evropske skupnosti, ki se nanašajo na to vsebinsko področje ${ }^{2}$.

Zakonodajalec se pri tem ni ustavil, pač pa je načelo enakega obravnavanja vgrajeval tudi $\vee$ nekatere druge sprejete predpise. Tako je prav gotovo zelo pomemben Zakon o delovnih razmerjih (ZDR), Ur.I. RS, št. 42/02, 79/06, 46/07 in 103/07. Šesti člen opredeljuje prepoved diskriminacije pri zaposlovanju, obema spoloma pa morajo biti zagotovljene enake možnosti in enaka obravnava pri zaposlovanju, napredovanju, usposabljanju, izobraževanju, prekvalifikaciji, plačah in drugih prejemkih iz delovnega razmerja, odsotnostih z dela, delovnih razmerah, delovnem času in odpovedi pogodbe o zaposlitvi. Zakon je podlaga za vladno Uredbo o ukrepih za varovanje dostojanstva zaposlenih $v$ organih državne uprave Ur. I. RS, št. 36/09, ki določa ukrepe, s pomočjo katerih se $v$ organih državne uprave zagotavlja delovno okolje, v katerem se spoštuje dostojanstvo vseh zaposlenih in kjer ni spolnega in drugega nadlegovanja in trpinčenja.

2 Direktiva Sveta 76/207/EGS z dne 9. februarja 1976 o izvrševanju načela enakega obravnavanja moških in žensk v zvezi z dostopom do zaposlitve, poklicnega usposabljanja in napredovanja ter delovnih pogojev (UL L št. 39 z dne 14. februarja 1976, str. 40), Direktiva Sveta 86/378/EGS z dne 24. julija 1986 o izvajanju načela enakega obravnavanja moških in žensk v poklicnih sistemih socialne varnosti (UL L št. 225 z dne 12. avgusta 1986, str. 40), Direktiva Sveta 2000/43/ES z dne 29. junija 2000 o izvajanju načela enakega obravnavanja oseb ne glede na raso ali narodnost (UL L št. 180 z dne 19. julija 2000, str. 22), Direktiva Sveta 2000/78/ES z dne 27. novembra 2000 o splošnih okvirih enakega obravnavanja pri zaposlovanju in delu (UL L št. 303 z dne 2. decembra 2000, str. 23), Direktiva 2002/73/ES Evropskega parlamenta in Sveta z dne 23. septembra 2002 o spremembi Direktive Sveta 76/207/EGS o izvrševanju načela enakega obravnavanja moških in žensk v zvezi z dostopom do zaposlitve, poklicnega usposabljanja in napredovanja ter delovnih pogojev (UL L št. 269 z dne 5. oktobra 2002, str. 15), Direktiva Sveta 2004/113/ES z dne 13. decembra 2004 o izvajanju načela enakega obravnavanja moških in žensk pri dostopu do blaga in storitev ter oskrbi z njimi (UL L št. 373 z dne 21. decembra 2004, str. 37) in Direktiva 2006/54/ES Evropskega parlamenta in Sveta z dne 5. julija 2006 o uresničevanju načela enakih možnosti ter enakega obravnavanja moških in žensk pri zaposlovanju in poklicnem delu (preoblikovano) (UL L št. 204 z dne 26. julija 2006, str. 23) 


\section{Roman Lavtar}

\section{Zagotavljanje enakosti spolov v slovenski lokalni samoupravi}

Državni zbor je oktobra 2005 sprejel še Resolucijo o nacionalnem programu za enake možnosti žensk in moških, 2005-2013 (ReNPEMZM) Ur. I. RS, št. 100/05 kot temeljni programski dokument za uresničevanje politike enakih možnosti. Resolucija določa šest prednostnih področij za uresničevanje enakosti spolov: integracija načela enakosti spolov, delo, družba znanja, družbena blaginja žensk in moških, odnosi med spoloma in procesi odločanja. Programski cilji in ukrepi, določeni z resolucijo, pa se določijo vsaki dve leti s periodičnim načrtom za izvajanje resolucije.

\section{Procesi odločanja in uresničevanje enakih možnosti moških in žensk}

$\checkmark$ našem prispevku nas posebej zanima področje procesov odločanja in $v$ tem kontekstu še posebej politično odločanje na lokalni ravni. Politična prizadevanja za določitev neposrednih ukrepov za povečanje udeležbe žensk v procesu političnega odločanja sicer segajo $v$ prva leta po osamosvojitvi. Že $v$ obdobju 1994 do 2002 je $\vee$ državnem zboru potekala živahna razprava o spremembah Zakona o političnih strankah, ki naj bi zavezoval politične stranke, da v svojih statutih določijo postopke in ukrepe za zagotavljanje enakih možnosti moških in žensk pri kandidiranju za volitve, vendar je bil zakon leta 2000 zavrnjen. Že omenjeni leta 2002 sprejeti Zakon o enakih možnostih žensk in moških pa je opredeljeval posebne ukrepe za uravnoteženo zastopanost zgolj kot priporočljive in ne pravno zavezujoče (Gortnar, 2004: 1034).

Ukrepe za doseganje uravnotežene zastopanost obeh spolov delimo $v$ tri sklope:

1. formalni (zakonska ureditev določenih ravnanj) in neformalni ukrepi (ki jih sprejmejo politične stranke ali druge interesne organizacije v svojih notranjih pravilih in programskih dokumentih);

2. ukrepi, ki vplivajo na kandidacijski postopek, in ukrepi, ki vplivajo na izvolitev, ter

3. ukrepi za financiranje in druge načine nagrajevanja in kaznovanja političnih strank za uravnoteženo sodelovanje obeh spolov $v$ političnem življenju (Grad, Nerad in Zagorc, 2004: 75).

Na politično zastopanost žensk vplivajo tri skupine dejavnikov: institucionalni, kulturni in socialnoekonomski. Med institucionalnimi je na prvem mestu 
volilni sistem. Ob številnih ukrepih bi za zagotovitev uravnotežene zastopanosti obeh spolov najbolje učinkovala določitev vnaprejšnjih kvot izvoljenih $\vee$ posameznem organu (ang. parity threshold), vendar bi bila taka rešitev sporna z vidika načela enakosti in enake volilne pravice. Zato se zakonodajalci odločajo za določitev kvot na kandidatnih listah ali določitev načina kandidiranja, po katerem morajo predlagatelji na kandidatnih listah zagotoviti tudi določen vrstni red kandidatov po spolu (sistem zadrge) ali kombinacijo obojega. $V$ večinskem sistemu se rešitve nekoliko zapletejo, toda tudi tam je mogoče $v$ volilnih enotah, kjer se voli več kot enega kandidata, zagotoviti enakomerno zastopanost spolov na kandidatni listi.

Zakonodajne rešitve, ki so $\vee$ Sloveniji sledile $\vee$ naslednjih letih za izenačevanja pogojev pri vključevanju $v$ procese odločanja o javnih zadevah, so $v$ materijo posegle z uporabo kvot in zadrge. Najprej je februarja 2004 z dopolnitvijo 16. člena Zakon o volitvah poslancev iz Republike Slovenije v Evropski parlament določil, da na kandidatni listi noben spol ne sme biti zastopan z manj kot 40 odstotki in da mora biti vsaka lista sestavljena tako, da je najmanj en kandidat vsakega od spolov uvrščen v zgornjo polovico liste (ZVPEP-UPB1) (Ur. I. RS, štev. 40/04). Tako je bila to prva $\vee$ praksi uveljavljena zakonodajna rešitev na prvih volitvah $\vee$ Evropski parlament, ki so se jih udeležili tudi kandidati iz Republike Slovenije junija 2004 in ki je z neposrednim zakonodajnim ukrepom vzpostavila uravnoteženo spolno sestavo kandidatnih list. Zaradi specifičnosti volitev (majhnega števila sedežev, ki se jih voli po proporcionalnem volilnem sistemu) je bilo število izvoljenih evropskih poslancev leta 2004 po spolu zelo uravnoteženo (štirje poslanci in tri poslanke), na volitvah 7. junija 2009 se je slika obrnila $v$ škodo ženskih poslank (pet poslancev in dve poslanki).

Julija 2005 je bil dopolnjen Zakon o lokalnih volitvah (Ur. I. RS, štev. 72/05). Določba $70 . b$ člena določa, da morajo predlagatelji kandidatnih list na lokalnih volitvah upoštevati zakonsko zahtevo po enakopravnem zastopanju obeh spolov na kandidatnih listah. Konkretna rešitev je podrobneje analizirana $\vee 4$. poglavju tega članka.

Med skoraj dvema ducatoma sprememb in dopolnitev, ki jih je bil deležen Zakon o volitvah v državni zbor, sprejet leta 1992 (Ur. I. RS, štev. 54/07), je bila z vidika zagotavljanja enakih možnosti obeh spolov pomembna sprememba leta 2007. Šesti odstavek 43. člena Zakona o volitvah v državni zbor odtlej določa, da na kandidatni listi noben spol ne sme biti zastopan z manj kakor 35\% od skupnega dejanskega števila kandidatk in kandidatov na listi. Ta zakonodajna norma je bila prvič v praksi uveljavljena na državnozborskih volitvah leta 2008. 


\section{Roman Lavtar}

\section{Zagotavljanje enakosti spolov v slovenski lokalni samoupravi}

Zaradi načina oblikovanja enajstih volilnih enot in znotraj njih volilnih okrajev ter zaradi načina izračunavanja volilnega rezultata (volitve po načelu sorazmernosti in D'Hontova formula izračunavanja in dodeljevanja ostanka glasov) številčna sestava izvoljenih poslank in poslancev ne odseva višine zapovedane kvote, zato med kvoto in volilnim rezultatom ni neposredne vzročne zveze: na od skupno 88 poslanskih sedežih (brez predstavnikov manjšin) $\vee$ parlamentu sedi le dvanajst žensk.

\section{Načelo enakih možnosti in normativne spremembe v lokalni samoupravi}

Omenili smo že, da je bil julija 2005 dopolnjen Zakon o lokalnih volitvah. Določba 70. b člena določa, da morajo predlagatelji kandidatnih list na lokalnih volitvah upoštevati zakonsko zahtevo po enakopravnem zastopanju obeh spolov na kandidatnih listah tako, da zagotovijo najmanj $40 \%$ vsakega od spolov, pri čemer morajo biti v prvi polovici na kandidatni listi kandidati zapisani izmenično. Kvota in zadrga, gre torej za identično rešitev, ki jo je zakonodajalec uveljavil pri volitvah $\vee$ Evropski parlament. Vendar bo ta rešitev $\vee$ celoti uveljavljena šele na rednih lokalnih volitvah leta 2014, saj zakon določa prehodno obdobje. Zakon postopno zvišuje kvoto, ki jo morajo upoštevati predlagatelji kandidatnih list, na obdobje dveh mandatov in razredči vrstni red kandidatov po spolu z vsakega drugega na vsakega tretjega (namesto moški - ženska predlagatelji lahko predlagajo moški - moški - ženska ali ženska - ženska moški) in ustvari nepopolno zadrgo. Tako so na prvih rednih volitvah po spremembi zakona jeseni 2006 predlagatelji morali zagotoviti najmanj 20 \% kandidatov vsakega od spolov, na naslednjih lokalnih volitvah 2010 pa jih bodo morali najmanj $30 \%$, pri čemer bodo morali kandidate $v$ prvi polovici kandidatne liste razporediti izmenično najmanj vsakega tretjega kandidata drugega spola.

Ne glede na morebitni vtis o polovičarski rešitvi zaradi prehodnega obdobja so se prvi učinki pokazali že na volitvah 2006. Pred tem je bilo v mandatnem obdobju med letom 2002 in letom 2006 občinskih svetih povprečno le 12 \% žensk, v kar 30 slovenskih občinah pa sploh nobene. Leta 1998 je bilo od 3830 kandidatk za občinski svet izvoljenih 380 (9,9\%), kar je pomenilo 12, 04 \% od vseh izvoljenih članov občinskih svetov. V letu 2002 se je ta številka povečala na 423 , vendar je to pomenilo le $13,09 \%$ od vseh izvoljenih občinskih svetnikov (tabela 2). 
Tabela 2: Kandidati in izvoljeni za župane in občinske svetnike po spolu

\begin{tabular}{|c|c|c|c|c|}
\hline & 1994 & 1998 & 2002 & 2006 \\
\hline Kandidati za župane/županje & 635 & 750 & 724 & 847 \\
\hline od tega število žensk & 31 & 53 & 77 & 91 \\
\hline Izvoljeni župani/županje & 147 & 192 & 193 & 210 \\
\hline od tega število žensk & 2 & 8 & 11 & 7 \\
\hline Kandidati za svetnike/svetnice & 16.820 & 20.786 & 23.426 & 26.721 \\
\hline od tega število žensk & 2.921 & 3.830 & 4.976 & 8.762 \\
\hline Delež žensk med kandidati za svetnike (\%) & 17,4 & 18,4 & 21,2 & 32,8 \\
\hline Izvoljeni svetniki/svetnice & 2.779 & 3.188 & 3.231 & 3.386 \\
\hline od tega število žensk & 299 & 384 & 423 & 728 \\
\hline Delež žensk med izvoljenimi svetniki (\%) & 10,8 & 12 & 13,1 & 21,5 \\
\hline
\end{tabular}

Vir: Lokalne volitve 1994 - 2006, Statistični urad Republike Slovenije, 2007

Rezultati za leto 2006 pa že kažejo izrazit vpliv nove zakonodajne rešitve. Število žensk se je pomembno povečalo med kandidati za občinske svétnike, od prvih volitev do volitev $\vee 2006$ se je skoraj podvojilo, medtem ko se je število izvoljenih občinskih svétnic $v$ enakem razdobju več kot podvojilo: z 10,8 \% $\checkmark$ letu 1994 na 21,5 \% v letu 2006. Učinek zadrge in kvote je očiten, ko primerjamo rezultata iz let 2002 in 2006. Čeprav se je število žensk med kandidati nenehno povečevalo (resda nekaj tudi na račun porasta števila občin), se je število izvoljenih žensk med svétniki pomembno zvišalo šele po tem, ko so bile te kandidatke uvrščene na kandidatne liste na izvoljiva mesta. Morebitni vpliv preferenčnih glasov je tozadevno nepomemben, ne glede na spol pa ima zaradi relativno visokega praga učinek $v$ izrazito majhnih volilnih enotah. Z več kot petino žensk med izvoljenimi občinskimi svétniki se je Slovenija zavihtela $\vee$ povprečje, ki so ga imele države članice Evropske unije pred desetimi leti, ko je bilo v povprečju z občinskih svetih 19,9 \% žensk (European Database: Women in Decision-making 1999, podatki dostopni na Uradu za enake možnosti Vlade Republike Slovenije). Stanje znotraj države se značilno ne razlikuje glede na razvitost, velikost slovenske občine in glede na njeno ozemeljsko razmestitev. Pregled stanja po statističnih regijah daje precej različno podobo, zastopanost 
Roman Lavtar

Zagotavljanje enakosti spolov v slovenski lokalni samoupravi

žensk v na primer najmanj razviti regiji Pomurju je skoraj enaka kot na Gorenjskem, ki spada med razvitejše regije.

Rezultati deležev izvoljenih občinskih svétnic glede na liste kandidatov ne kažejo izrazitega odstopanja. Če opazujemo samo parlamentarne stranke in njihove rezultate na lokalnih volitvah, se je med letoma 2002 in 2006 opazno povečalo število svétnic iz vrst Slovenske demokratske stranke SDS (za 61,3 \%), Slovenske ljudske stranke SLS (za $42 \%$ ), Liberalne demokracije Slovenije LDS (za 41,2 \%), Demokratične stranke upokojencev DeSUS (za 39 \%) in Socialnih demokratov SD (za $30 \%$ ). Delež žensk kljub zakonodajnim ukrepom beleži manjšo rast v Slovenski nacionalni stranki SNS (samo za $20 \%$ ) in v Novi Sloveniji NSi (skromnih 8 \%) (Tabela 3). Seveda bi bilo treba za objektivno sliko te rezultate primerjati z doseženim celotnim rezultatom, ne glede na to pa je nedvoumno, da so vse stranke $v$ primerjanem obdobju povečale število kandidatk na kandidatnih listah za 11,6 \%. Večina kandidatnih list na volitvah $2006 \mathrm{v}$ primerjavi z letom 2002 je presegla 30 odstotni delež žensk, kar se prej ni nikoli zgodilo in temu primeren je tudi skupen porast števila izvoljenih žensk iz 13,1 \% na kar 21,5\% (Lokalne volitve .., 2007: 18).

Tabela 3: Delež izvoljenih občinskih svétnic glede na liste kandidatov

\begin{tabular}{|l|c|c|c|c|}
\hline & 1994 & 1998 & 2002 & 2006 \\
\hline DeSUS & 13,4 & 15,0 & 12,7 & 20,8 \\
\hline LDS & 12,0 & 13,0 & 14,7 & 25,0 \\
\hline Nsi (SKD) & 10,5 & 11,4 & 13,3 & 14,5 \\
\hline SD (ZL, ZLSD) & 18,2 & 18,5 & 19,1 & 27,5 \\
\hline SDS (SDSS) & 9,0 & 9,9 & 9,2 & 23,8 \\
\hline SLS & 7,8 & 9,9 & 10,3 & 17,8 \\
\hline SMS & - & - & 15,8 & 25,0 \\
\hline SNS & 12,7 & 9,1 & 9,5 & 11,8 \\
\hline Neodvisni kandidati & 9,3 & 12,3 & 13,5 & 19,7 \\
\hline SKUPAJ & 10,8 & 12,0 & 13,1 & 21,5 \\
\hline
\end{tabular}

Vir: Lokalne volitve 2004 - 2006, Statistični urad Republike Slovenije, 2007 
$\checkmark$ treh četrtinah vseh občin volitve potekajo po proporcionalnem volilnem sistemu, tam volijo od 12 do 45 svetnikov, $v$ preostalih manjših občinah volijo od 7 do največ 11 svétnikov po večinskem načelu. Slednje največkrat nimajo več kot 2000 prebivalcev.

Tabela 4: Občine glede na volilni sistem

\begin{tabular}{|l|c|c|c|c|}
\hline & 1994 & 1998 & 2002 & 2006 \\
\hline $\begin{array}{l}\text { Občine s proporcionalnim } \\
\text { volilnim sistemom }\end{array}$ & 131 & 144 & 145 & 150 \\
\hline $\begin{array}{l}\text { Občine z večinskim } \\
\text { volilnim sistemom }\end{array}$ & 147 & 192 & 193 & 210 \\
\hline Število občin - skupaj & & & & \\
\hline
\end{tabular}

Vir: Lokalne volitve 1004 - 2006, Statistični urad Republike Slovenije, 2007

Primerjava med volilnima sistemoma ne kaže pomembnih razlik (Tabela 4), vendar je proporcionalni volilni sistem nekoliko bolj naklonjen svétnicam kot večinski. $V$ občinah s proporcionalnim volilnim sistemom je bilo namreč na volitvah 2002 izvoljenih 13 \% svétnic, v preostalih pa 10 \% (Lavtar, 2007: 74 75). Razlika se utegne $\vee$ prihodnje povečevati, saj $\vee$ večinskem volilnem sistemu ni mogoče $v$ celoti zagotoviti načela kvot in zadrge. Hkrati je pri sodbi o vlogi volilnega sistema na število žensk $v$ občinskih svetih pomembno upoštevati, da se je število občin s proporcionalnim volilnim sistemom od leta 1994 do 2006 povečalo za trikrat in da so v prvem krogu lokalnih volitev 2006 po večinskem načelu volili $\vee 60$ občinah, toda $\vee$ teh je prebivalo le $6,1 \%$ vseh volilnih upravičencev (Lokalne volitve, 2007: 4).

\section{Sklep}

Urad Vlade Republike Slovenije za enake možnosti je leta 2007 ob finančni pomoči Evropske unije izdal Smernice za enakost žensk in moških v lokalnem razvoju $^{\mathbf{3}} v$ katerih je sistematično razčlenil različne vrste aktivnosti, ki jih za doseganje enakih možnosti poleg zakonodajnih ukrepov države lahko izvedejo lokalne oblasti. Raziskava, izvedena $\vee$ slovenskih lokalnih skupnostih $\vee$ letu

3 Smernice za enakost žensk in moških v lokalnem razvoju so nastale v okviru mednarodnega projekta "Enakost spolov v lokalnem razvoju ("Gender equality in Local Development"), v katerem so sodelovali Luksemburg, Danska in Slovenija. 


\section{Roman Lavtar}

\section{Zagotavljanje enakosti spolov v slovenski lokalni samoupravi}

2003, navaja nekaj predlogov strateških ciljev za lokalne skupnosti (Dobnikar, 2004: 51): seznaniti lokalne skupnosti in njihove organe z obstojem, mnenji, cilji, strategijami, mogočimi ukrepi in učinki politike enakih možnosti, motivirati lokalne skupnosti za uveljavljanje ter oblikovanje politike enakih možnosti, imenovanje koordinatoric/koordinatorjev enakih možnosti v lokalnih skupnostih, medsebojno sodelovanje lokalnih skupnosti in koordinatorjev enakih možnosti, seznanjanje organov lokalnih skupnosti z delom nevladnih organizacij za enake možnosti itd.

Pozivom h konkretnim aktivnostim lokalnih skupnosti se pridružuje tudi Kongres lokalnih in regionalnih oblasti (CLRAE) pri Svetu Evrope, ki od lokalnih skupnosti pričakuje, da se bodo trdneje obvezale k uresničevanju akcijskih načrtov za uveljavitev enakosti spolov, da bodo promovirale enake možnosti, da bodo temu prilagodile odločevalske procese, da bodo sistematično zbirale podatke o zastopanosti spolov, zagotovile usposabljanje za lokalne politike in političarke itd. K zgodnjemu spodbujanju enakopravnosti spolov nas opozarja Evropska listina o sodelovanju mladih $v$ občinskem in regionalnem življenju (2003: Revised Charter, poglavje I.7). V njej je izraženo pričakovanje, da bodo lokalne in regionalne oblasti spodbujale enakopravnost "od zgodnjega otroštva dalje«, da bodo pripravile načrt, kako bodo to počele, preverjale in ocenjevale metode, s katerimi bodo zagotavljale enakopravnost med spoloma pri mladih in omogočale dekletom in mladim ženskam informacije o izobraževalnih možnostih ter pridobivanje poklicnih kvalifikacij tudi za tradicionalno moške poklice.

Že prej omenjena Resolucija o nacionalnem programu za enake možnosti žensk in moških za obdobje 2005-2013 kot temeljni slovenski programski dokument za uresničevanje politike enakih možnosti določa šest prednostnih področij za uresničevanje enakosti spolov. Poleg procesov odločanja, ki smo jih podrobneje obravnavali $\vee$ našem prispevku, resolucija opredeljuje tudi integracijo načela enakosti spolov $v$ vsa področja družbenega življenja, $v$ svet dela in izobraževanja, obravnava družbeno blaginjo žensk in moških in se posebej opredeljuje do odnosov med spoloma.

Skratka, niso le kvote tiste, ki vodijo k doseganju zastavljenih ciljev, so pa pomemben vzvod za doseganje drugih ciljev. $\vee$ prispevku smo ugotovili, da na politično zastopanost žensk vplivajo tri skupine dejavnikov: poleg institucionalnih, kamor sodijo zakonodajni posegi $v$ volilno zakonodajo, niso nič manj pomembni tudi kulturni in socialnoekonomski dejavniki. Število žensk $\vee$ politiki, državni in lokalni, pritrjuje $\vee$ prid tezi, da Slovenija poleg urejenih institucionalnih 
mehanizmov za spodbujanje enake zastopanosti žensk in moških potrebuje še druge, mehke ukrepe in spremembo družbenih vrednot.

Dr. Roman Lavtar je magisterij in doktorat opravil na Fakulteti za družbene vede Univerze v Ljubljani. Trenutno je zaposlen v Službi Vlade Republike Slovenije za lokalno samoupravo in regionalno politiko. Predava na strokovnih srečanjih s področja javne uprave in lokalne samouprave na Upravni akademiji Ministrstva za javno upravo, občasno pa tudi na Fakulteti za družbene vede Univerze v Ljubljani. Sodeluje s Fakulteto za upravo Univerze $v$ Ljubljani pri predmetih Lokalno samouprava in Teorija javne uprave. Teme njegovega strokovnega in teoretskega zanimanja so lokalna samouprava, teorija javne uprave, usposabljanje javnih uslužbencev in participacija prebivalcev pri odločanju. 


\section{Roman Lavtar}

\section{Zagotavljanje enakosti spolov v slovenski lokalni samoupravi}

\section{Literatura}

- $\quad$ Antić Gaber, M. in Mencin, M. (1992).Ženske in politika, v zborniku Ženske v Sloveniji, Ko odgrneš 7 tančic, str. 103 - 111. Ljubljana: Društvo iniciativa.

- Dobnikar, M. in Selišnik, I. (2004) Enake možnosti, lokalne skupnosti in ženske nevladne organizacije. str. 51 -52. Ljubljana: Društvo za uveljavljanje enakosti in pluralnosti Vita Activa,

- Gortnar, M. (2004): Razprave o kvotah v slovenskem parlamentu, Teorija in praksa, 56/2004, pp. $1034-1050$

- Grad, F., Nerad, S. in Zagorc, S. (2004). Volilni sistem Republike Slovenije za lokalne volitve, elaborat Inštituta za primerjalno pravo pri Pravni fakulteti Univerze v Ljubljani, september 2003, objavljeno v zborniku Dokumenti in študije o pokrajinah v Sloveniji 2000 - 2004, urednik Lavtar R., Ljubljana: Ministrstvo za notranje zadeve RS.

- Held, D. (1989). Modeli demokracije, Ljubljana: Krt.

- Lavtar, R. (2007). Sodelovanje prebivalcev v slovenskih občinah, Participacija prebivalcev pri odločanju o javnih zadevah na lokalni ravni v Sloveniji. Maribor: Lex localis.

- Melik, V.(1965). Volitve na Slovenskem 1861 - 1918. Ljubljana: Slovenska matica v Ljubljani.

- Mill, J. S. (1988) Izabrani politički spisi, prvi svezak, Biblioteka politička Misao. Zagreb: Informator.

- Wollstonecraft, M.(1993). Zagovor pravic ženske. Ljubljana: Krt.

- (2007). Lokalne volitve 1998 - 2006. Ljubljana: Statistični urad Republike Slovenije.

- (2003). Revised European charter on the participation of young people in local and regional life (Charter without the status of convention) CLRAE Congress of local and regional Authorities of Europe, 21. maj 2003, http://www.coe.int/T/E/Clrae/

- (1995). The gender perspective. Parliamentary assembly, Strasbourg: Council of Europe Publishing. 


\section{SUMMARY}

\section{GENDER MAINSTREAMING IN SLOVENE LOCAL SELF-GOVERNMENT}

In the last decade gender mainstreaming gets in professional and political public more attention than in the past years. Numerous incentives supported by legislative measures and establishment of a specialised government body which exercises a systematic survey of the topic enabled a giant leap in understanding the social role of gender relationship as well as concrete results in achieving goals in gender mainstreaming in Slovenia. The author systematically evaluates circumstances in system of local self-government as vertically decentralized subsystem of public authority. From the quantitative point of view he assesses improvement in women's participation in decision making process at local level. The author predicts further improvement and strengthening of women's role in local political life as in future increased number of women's candidates will create a significant number of local women politicians and conditions in which both men and women will tend to use quota and other measures for protecting their rights.

In the first part of the article the author shortly describes the history of gender mainstreaming movement with political and philosophical background of struggle for women's equality in public life. For a long period of time woman was understood as politically unfit and immature. Even in the oldest known democracy in ancient Greece women, slaves and foreigners were not allowed to participate in decision-making process. The situation was not altered after the birth of the modern state when Machiavelli changed the understanding of the medieval times. It took almost further four centuries for John Stuart Mill and Mary Wollstonecraft to define that the modern liberal state has to protect ethnic minorities and women. In accordance to Mill only an absolute equality of men and women can create circumstances for human freedom and democracy. And Wollstonecraft pointed out that the fact that one half of the mankind was excluded from governing was a phenomenon that could not be explained by abstract principles. In spite of the fact they were both English Great Britain was not the first state to recognise women's right to vote and stand as a candidate, but New Zealand was in 1893. Slovene women got the voting right only before and after Word War I, although for some period of time under Habsburg monarchy they were not allowed to execute it on their own but through their fathers, brothers and husbands. 


\section{Roman Lavtar}

\section{Zagotavljanje enakosti spolov v slovenski lokalni samoupravi}

In last quarter of the 20-th century the question of women's participation in public life came to the top of the political agenda of many international organisations. Universal suffrage is not the only today's issue. More than before the so-called parity democracy puts the question whether the democracy is still democracy without equal representation of men and women. Parity democracy demands equal representation in all aspects of public life, political as well. In 1991 there were only $11 \%$ of women in national parliaments all over the world and only 12, 5 \% in European Union. After the fall of Berlin wall the numbers decreased which proves that more democracy doesn't necessary mean more women in politics. The concept of parity democracy is de iure and de facto equality and rejects cultural relativism as an argument against. Culture, religion or tradition ought not be obstacles. It also requires from states taking explicit measures to fulfil the legitimate rights of women.

In the second part of the article the author analyses the development of gender mainstreaming in Slovenia after becoming an independent state in 1991. He presents the legal documents that provided realisation of women's rights in public life including those related to work place, health, education and political representation. In the third part of the article the author develops this subject in detail, expounding that measures for equal participation of women in public life can be divided in three groups: 1) formal (legal instruments introduced through legislative state organs) and informal measures (internal rules of procedure or program documents of political parties and other organizations), 2) measures related to candidacy and election procedures and 3) financial bonuses or fines of political parties for promoting gender equality. He also points out that there are other three groups of factors influencing the level of women's participation in public life: institutional, cultural and socioeconomic.

Further he describes the legal instruments adopted in Slovenia as incentives for women's participation in political life. First, in February 2004 the European Election Act was adopted, including the obligation of political parties or other submitters of candidacy lists to put at least $40 \%$ of both men and women on the list. In addition in the first half of the list candidates must be classified in turn. In July 2005 the Local Election Act was amended in similar way but with a transitional period of twelve years i.e. $40 \%$ of both genders will be obligatory only in local elections in 2014 . And lastly, in 2007 the National Parliament Election Act was amended. It provides obligation for $35 \%$ of each gender on candidacy lists of political 
parties. Since the election rules provide also eight constituencies, this measure doesn't have the same impact on women's representation in national parliament. So in spite of that legislative measure only $13,6 \%$ of women were elected in the general elections in 2008.

In the last part of the article the author analyses in detail the participation of women at local level. He compares numbers of nominated and elected women candidates in all four elections since Slovene independence. He finds out that before introducing incentive legal measures for more women in local politics only one tenth of members of local councils were women. But after amendment of the Local election Act in 2005 in the local elections next year the outcome was doubled. In the local elections in 2006 the share of women candidates rose from 17,4 \% in 1994 to 32,8\% in 2006 and number of elected women members of local councils rose from $10,8 \%$ in 1998 to $21,5 \%$ in 2006 . The result varied from political part to party but did not from region to region. 